\section{Commentary: Mind the gap: Adherence to quality measures for stage I/II non-small cell lung cancer}

\author{
Jules Lin, MD
}

In this issue of the Journal, Khorfan and colleagues ${ }^{1}$ report significant gaps in the delivery of care in patients with lung cancer by evaluating adherence to 7 quality measures using the National Cancer Database (NCDB). Two surgical (lymph node sampling and anatomic resection for $\mathrm{T} 1 \mathrm{~b}$ tumors) and 2 care coordination measures (adjuvant chemotherapy for stage II tumors and biopsy before radiation) with poor compliance were identified. Other quality measures have been developed by the National Comprehensive Cancer Network and the American College of Surgeons Commission on Cancer, but as the authors point out, each only addresses limited aspects of lung cancer care.

The authors should be commended for their in-depth analysis of the NCDB, which allowed a large number and wide range of patients and hospitals to be evaluated. However, as the authors acknowledge, there are a number of important limitations in using the NCDB. Although they initially identified 18 quality measures, only 7 could be assessed due to the limited data available. In addition, some of the measures that were assessed lacked the granularity needed to determine true adherence. Even when resection was $\mathrm{R} 0$, there were no data on whether the margin was $\geq 2 \mathrm{~cm}$, and although lymph node sampling was performed, the number and lymph node stations were not included. In their evaluation of attributable variance, surgical measures were more likely to be provider rather than hospital-specific, and $84 \%$ to $89 \%$ of hospital-level variation was not accounted for in the full model due to limited data.

\footnotetext{
From the Section of Thoracic Surgery, Department of Surgery, University of Michigan Medical Center, Ann Arbor, Mich.

Disclosures: The author reported no conflicts of interest.

The Journal policy requires editors and reviewers to disclose conflicts of interest and to decline handling or reviewing manuscripts for which they may have a conflict of interest. The editors and reviewers of this article have no conflicts of interest.

Received for publication May 29, 2020; revisions received May 29, 2020; accepted for publication June 1, 2020; available ahead of print June 26, 2020.

Address for reprints: Jules Lin, MD, Section of Thoracic Surgery, 1500 E. Medical Center Dr, 2120TC/5344, Ann Arbor, MI 48109-5344 (E-mail: juleslin@umich. edu).

J Thorac Cardiovasc Surg 2021;162:661-2

$0022-5223 / \$ 36.00$

Copyright (C) 2020 by The American Association for Thoracic Surgery

https://doi.org/10.1016/j.jtcvs.2020.06.032
}

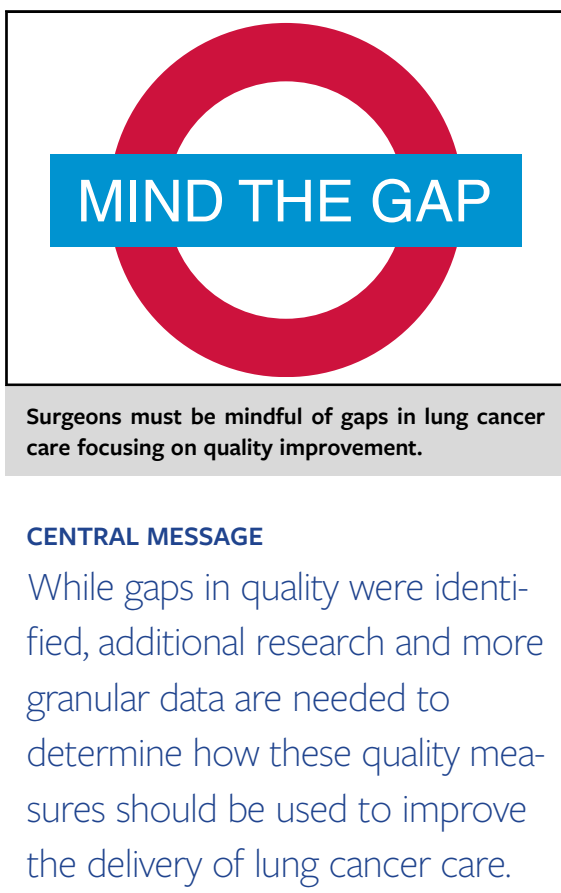

Five of the quality measures were significantly associated with survival. Samson and colleagues ${ }^{2}$ also found that the 4 quality measures they evaluated were associated with survival. Adherence with all 4 measures was most strongly associated with survival, and a composite of the quality measures in the current study may be most useful in evaluating quality of care. The authors state that their goal was to provide specific, actionable targets for improvement in cancer care delivery. Although these measures would be useful for quality assurance and performance improvement, it is unclear what role they could play with increasing interest in public reporting, ${ }^{3}$ value-based reimbursement, and program certification. ${ }^{4}$

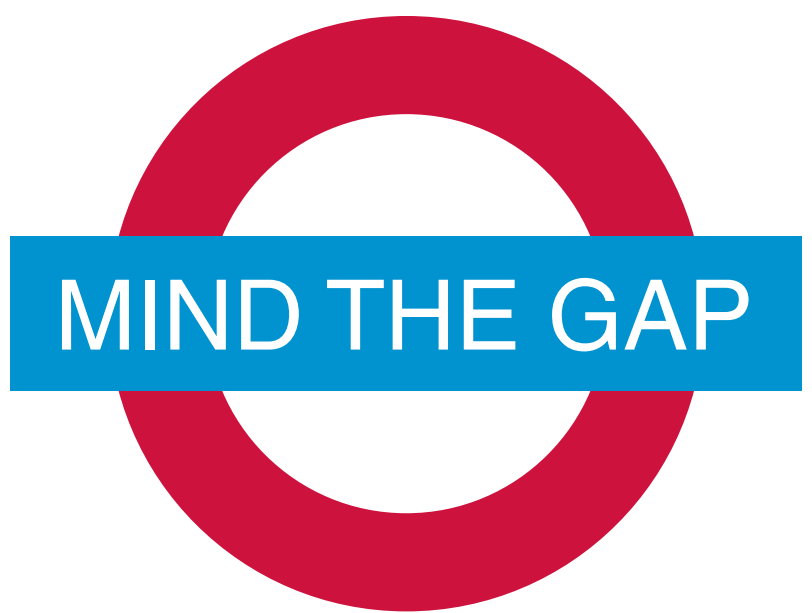

FIGURE 1. Surgeons must be mindful of gaps in lung cancer care focusing on quality improvement. (Image designed by Mia Lin.) 
Regionalization of care has been proposed as a potential way to improve outcomes for patients undergoing complex surgeries. ${ }^{5,6}$ Would referring patients to hospitals meeting these quality measures improve outcomes? Interestingly, highvolume academic centers actually had lower adherence with coordination of care measures, such as referral for chemotherapy for stage II tumors and obtaining a biopsy before radiation treatment, which may be due to difficulty coordinating care in larger medical centers and communicating with outside hospitals.

Although gaps in quality were identified, additional research and more granular data are needed to determine how these quality measures should be used to improve the delivery of lung cancer care. Just as one should take caution when stepping onto the London Underground, it is important that surgeons make a conscious effort to "mind the gap," remaining mindful of gaps in lung cancer care and focusing on quality improvement (Figure 1).

\section{References}

1. Khorfan R, Cooke DT, Meguid RA, Backhus L, Varghese TK, Farjah F, et al; the ThORN Collaborative. the ThORN Collaborative. Institutional factors associated with adherence to quality measures for stage I and II non -small cell lung cancer. J Thorac Cardiovasc Surg. 2021;162:649-60.e8.

2. Samson P, Crabtree T, Broderick S, Kreisel D, Krupnick AS, Patterson GA, et al. Quality measures in clinical stage I non-small cell lung cancer: improved performance is associated with improved survival. Ann Thorac Surg. 2017;103: 303-11.

3. Kozower BD, O'Brien SM, Kosinski AS, Magee MJ, Dokholyan R, Jacobs JP, et al. The Society of Thoracic Surgeons composite score for rating program performance for lobectomy for lung cancer. Ann Thorac Surg. 2016; 101:1379-87.

4. Brunelli A, Rocco G, Van Raemdonck D, Varela G, Dahan M. Lessons learned from the European thoracic surgery database: the composite performance score. Eur J Surg Oncol. 2010;3(suppl 1):S93-9.

5. Wakeam E, Hyder JA, Lipsitz SR, Darling GE, Finlayson SR. Outcomes and costs for major lung resection in the United States: which patients benefit most from high-volume referral? Ann Thorac Surg. 2015;100:939-46.

6. Resio BJ, Chiu AS, Hoag JR, Brown LB, White M, Omar A, et al. Motivators, barriers, and facilitators to traveling to the safest hospitals in the United States for complex cancer surgery. JAMA Netw Open. 2018;1:e184595.
See Article page 649.

\section{Commentary: Nonadherence to guidelines: It is important to investigate the reasons and survival outcomes}

\author{
Yang Zhang, MD, ${ }^{\mathrm{a}, \mathrm{b}, \mathrm{c}}$ and \\ Haiquan Chen, $\mathrm{MD}, \mathrm{PhD}^{\mathrm{a}, \mathrm{b}, \mathrm{c}}$
}

To ensure patients are receiving guideline-concordant care, the Thoracic Surgery Outcomes Research Network developed a list of quality measures for the management of non-small cell lung cancer. Khorfan and colleagues ${ }^{1}$ aimed to evaluate baseline adherence to these Thoracic

\footnotetext{
From the ${ }^{\mathrm{a} D e p a r t m e n t s ~ o f ~ T h o r a c i c ~ S u r g e r y ~ a n d ~ S t a t e ~ K e y ~ L a b o r a t o r y ~ o f ~ G e n e t i c ~ E n-~}$ gineering, Fudan University Shanghai Cancer Center, Shanghai; ${ }^{b}$ Institute of Thoracic Oncology, Fudan University, Shanghai; and ${ }^{\mathrm{c}}$ Department of Oncology, Shanghai Medical College, Fudan University, Shanghai, China.

Disclosures: The authors reported no conflicts of interest.

The Journal policy requires editors and reviewers to disclose conflicts of interest and to decline handling or reviewing manuscripts for which they may have a conflict of interest. The editors and reviewers of this article have no conflicts of interest.

Received for publication May 13, 2020; revisions received May 13, 2020; accepted for publication May 13, 2020; available ahead of print May 31, 2020.

Address for reprints: Haiquan Chen, MD, PhD, Department of Thoracic Surgery, Fudan University Shanghai Cancer Center, 270 Dong-An Rd, Shanghai 200032, China (E-mail: hqchen1@yahoo.com).

J Thorac Cardiovasc Surg 2021;162:662-3

$0022-5223 / \$ 36.00$

Copyright (c) 2020 by The American Association for Thoracic Surgery

https://doi.org/10.1016/j.jtcvs.2020.05.056
}

Check for updates

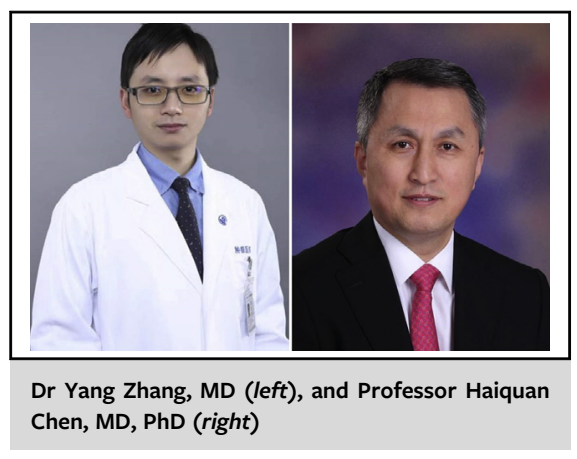

CENTRAL MESSAGE

This study highlights the need for

improvement in adherence to

guidelines. However, it is impor-

tant to further investigate the

reasons and survival outcomes

associated with nonadherence.

Surgery Outcomes Research Network quality measures. They investigated 253,182 patients from 1324 hospitals in the National Cancer Database. It can be expected that they found lower-volume and nonacademic institutions were associated with inadequate nodal sampling and nonanatomic resection. However, it is quite surprising that greater-volume and academic institutions were 